\title{
Who Teams Up with the European Parliament? Examining Multilevel Party Cooperation in the European Union
}

\author{
Katharina L. Meissner ${ }^{1 *}$ (D) and Guri Rosén ${ }^{2}$ (D) \\ ${ }^{1}$ University of Vienna, Centre for European Integration Research (EIF), Vienna, Austria and ${ }^{2}$ ARENA \\ Centre for European Studies, Oslo Metropolitan University, Oslo, Norway \\ ${ }^{*}$ Corresponding author. Email: Katharina.meissner@univie.ac.at
}

(Received 17 March 2021; revised 7 July 2021; accepted 20 August 2021)

\begin{abstract}
As in nearly all European Union (EU) policy areas, scholars have turned to analysing the role of national parliaments, in addition to that of the European Parliament (EP), in trade politics. Yet, there is limited understanding of how the parliamentarians at the two levels interact. This article fills the gap by conceptualizing these interactions as a continuum ranging between cooperation, coexistence and competition. We use this continuum to explore multilevel party interactions in EU trade talks and show how cooperation compels politicization - national parliamentarians mainly interact with their European colleagues in salient matters. However, we argue that the impact of politicization on multilevel relations between parliamentarians in the EP and national parliaments is conditioned by party-level factors. Hence, we account for how and why politicization triggers multilevel party cooperation across parliaments in the EU through ideological orientation, government position and policy preferences and show how this takes place in the case of trade.
\end{abstract}

Keywords: EU external relations; European Parliament; national parliaments; trade

The European Union (EU) is built on the principle of representative democracy. European citizens are directly represented through the European Parliament (EP), and indirectly through their national governments, which are accountable to national parliaments (NPs) (Article 10, Treaty on European Union). How to translate these principles into respective power and roles, however, has proven contentious, and empirical knowledge on how these representative bodies relate to each other in EU politics is scant (Herranz-Surrallés 2014; Miklin 2013; Winzen et al. 2015).

Although there are interesting studies of how national parties control their members of the EP (MEPs) (e.g. Carter and Poguntke 2010; Lyder-Hermansen 2018; Mühlböck 2012), the question of how parliamentarians interact in concrete instances of decision-making has remained untapped so far. Do they cooperate?

(C) The Author(s), 2021. Published by Cambridge University Press on behalf of Government and Opposition Limited. This is an Open Access article, distributed under the terms of the Creative Commons Attribution licence (https://creativecommons.org/licenses/by/4.0/), which permits unrestricted re-use, distribution, and reproduction in any medium, provided the original work is properly cited. 
Are they in competition? Or do they simply coexist? Because the most likely scenario is a combination of these types of relationships, it is necessary to investigate the conditions under which different forms of interaction occur. Hence, in this article, we ask why these different forms occur and, consequently, why interaction among parliamentarians varies. To this end, we develop a framework of different forms of interaction and the conditions under which multilevel cooperation as one form of interaction is expected to arise. We assess our framework on the variation of relations between parliamentarians in the EP and a set of similar NPs - Austria, Germany and Sweden - in EU trade politics.

Trade makes for a particularly interesting case to examine parliamentarians' multilevel relations. First, not only did the Lisbon Treaty grant the EP the right to ratify trade agreements, but NPs have also become active in trade politics (Roederer-Rynning and Kallestrup 2017). Second, the negotiations of several of the EU's trade agreements have become contested in domestic public opinion, especially the negotiations on the Comprehensive Economic Trade Agreement (CETA) with Canada and the negotiations on the Transatlantic Trade and Investment Partnership (TTIP) with the USA.

Our contribution in this article is threefold. First, we offer a fine-grained conceptualization of interactions among parliamentarians on different parliamentary levels, ranging from competition, to coexistence, to cooperation. This allows us to analyse the range of relations across multiple levels beyond a dichotomy of cooperation and conflict. Hence, what we aim to provide is a nuanced understanding of the forms of interaction that take place between parliamentarians at the two levels.

Second, we put forward a theoretical account of when we might expect cooperation as one form of multilevel party interaction. Thus, our explanatory interest lies primarily in multilevel cooperation rather than in other forms of interaction. Previous research has shown salience to be an important factor, something that is corroborated by our study. However, we argue that the impact of politicization on multilevel interactions among parliamentarians is conditioned by party-level factors. More specifically, we argue that politicization is necessary but not sufficient on its own for cooperation. In order to understand why parliamentarians cooperate across levels, we need to take into account a range of partisan factors - ideology, preferences and office-holding - that in combination urge them to interact cooperatively.

Third, empirically, we add to the existing literature on multilevel relations, which has thus far focused mainly on interparliamentary cooperation through bodies such as the Conference of Parliamentary Committees for Union Affairs of Parliaments of the EU (COSAC), candidate selection and variations in efforts at control (e.g. Cooper 2015; Mühlböck 2012; Raunio 2000). Moreover, whereas the respective roles of the EP and NPs in EU trade policy are well understood, investigation into patterns of interaction between them, and their parliamentarians, is less developed.

We proceed as follows. In the theoretical section, we first develop our conceptualization of interactions among parliamentarians across parliamentary levels. Next, we offer a theoretical framework for explaining the conditions under which multilevel party cooperation can be expected. In the research design section, we set out 
our case selection rationale, the research strategy and our data, including parliamentary documents and interviews with officials from Austria, the EP, Germany and Sweden. In the empirics, we assess the range of interactions among parliamentarians across the EP and NPs and explore our theoretical framework on these relations in trade politics. The conclusion discusses the results and reflects on avenues for further research.

\section{Theoretical expectations}

In setting out the continuum between cooperation and competition, and in building our explanatory framework for multilevel party interactions on this continuum, we draw on scholarship analysing coordination, which we combine with literature on interparliamentary interaction. In this section, we first develop a fine-grained continuum for considering such relations. Second, we set up theoretical expectations on when we might observe multilevel party cooperation across the EP and NPs.

\section{Cooperation, coexistence, competition}

The EU has been described as a multilevel parliamentary system, where parliamentary actors are connected across levels of governance (Crum and Fossum 2009). MEPs are directly elected at the national level. In the EP, they become part of ideological party groups to which their national parties belong. MEPs' main principals are the national parties, who select the candidates in EP elections, and the supranational party groups, who control the internal affairs of the EP (Hix 2002: 688). However, previous studies have demonstrated that there are considerable variations in how far national parties attempt to control the legislative behaviour of their transnational colleagues (Mühlböck 2012). Elisabeth Carter and Thomas Poguntke (2010) have, for example, shown how voting instructions are rare. Based on a survey of national parties, Tapio Raunio (2000) observed that contacts between MPs and MEPs were mainly through personal ties. Roman Senninger and Daniel Bischof (2018) show that multilevel interaction on policy issues happens primarily within the same party branch.

How then are we to understand what characterizes the cross-border interaction between party actors, including their parliamentarians? We suggest that such multilevel relations should be conceptualized as a continuum ranging between two poles: cooperation and competition. On one end, cooperation resembles an interaction of 'coordination [where] all actors can maximize their payoffs by agreeing on concerted strategies' (Scharpf 1997: 73). Competition is the exact opposite of cooperation. It denotes a zero-sum situation where actors are weary of the distributive consequences of their interaction. Parliaments and parties may fear their competences will be undermined by growing competences of parliaments on another level (Eisele 2017). Conflict can also occur where actors endorse differing proposals, implying distributive consequences. Between these two extremes, relations can vary between being complementary, in the form of division of labour (Eisele 2017), or a mere coexistence without any positive or negative amplitude (Table 1). We think of these categories as degrees on a continuum of interaction, which are not to be 
Table 1. Cooperation, Coexistence, Competition: Typology and Operationalization

\begin{tabular}{lll}
\hline Continuum & Type of Interaction & \multicolumn{1}{c}{ Implications } \\
\hline Cooperation & Positive coordination & $\begin{array}{l}\text { Active coordination of preferences/ } \\
\text { strategies and development of joint position }\end{array}$ \\
\cline { 2 - 3 } & Negative coordination & $\begin{array}{l}\text { Vertical division of labour, arbitration } \\
\text { and conflict avoidance }\end{array}$ \\
\hline & Information exchange & Exchange of documents, information and positions \\
\hline Competition & Conflict & $\begin{array}{l}\text { Unilateral action in order to gather information, } \\
\text { documents or expertise/ independent } \\
\text { decision-making }\end{array}$ \\
\hline
\end{tabular}

Source: Authors' own illustration.

understood as mutually exclusive. Rather, we are interested in observing patterns of how political actors move on the proposed continuum.

The literature on the EP and NPs contains several examples of multilevel party cooperation. The positive extreme is coordination, where parliamentary actors work on joint positions or strategies. Such coordination can take place via personal, face-to-face meetings, phone calls or email exchange as well as through joint events, hearings or conferences and delegations (Miklin and Crum 2011: 6-7). The essence is that parliamentarians actively coordinate their preferences and try to find common positions vis-à-vis third actors. This may include the establishment of central priorities (Metcalfe 1994) or forms of strategic coordination - developing programmes around strategic goals (Peters 1998: 3). In the ultimate form, parties and parliamentarians may even ally on particular issues (Haroche 2018).

Moving down the continuum, coordination could also occur in a 'negative' form where parliamentarians actively seek to avoid conflict (Scharpf 1994). This could entail demarcating limits of engagement between MPs and MEPs, making sure that both parties are aligned on their respective role expectations. It could also mean arbitration between policy differences so that initiatives at various parliamentary levels do not clash, or at least that efforts are made to avoid divergences between parliamentarians (Metcalfe 1994). These forms of complementary relations among political actors represent efforts of a division of labour at an EP and NP level. Here, parliamentarians divide their tasks based on the division of powers or the level of executives they seek to scrutinize.

Multilevel coordination may also be less vivid and rather centre on consultation and information exchange. We locate an exchange of information further down the continuum and as less 'cooperative' than negative coordination, because here political actors do not actively coordinate their preferences or strategies. The quality of interactions under a mere information exchange differs from negative coordination as exchange of information does not require activities such as arbitration or alignment. An exchange of information or documents is most frequently reported in the literature through conferences, newsletters and briefings, delegations, personal contacts between MEPs and MPs (Neunreither 2005). 
Towards the other end of the continuum of multilevel interactions, we find noncooperative relations, where party political actors pursue unilateral, rather than collaborative or concerted, action (Scharpf 1997: 43). This can take the form of a mere coexistence of parliamentarians in the EP and NPs, independent decision-making or even competition. Coexistence may mean that parliaments at the national and EU levels and their actors make policies independent of each other through unilateral parliamentary oversight, the organization of separate events or the utilization of their own expertise, for example (Metcalfe 1994).

Competition, by contrast, counts as a conflictual situation where actors see each other as a potentially undermining power (Winzen et al. 2015) or where they compete over certain policy outcomes. This can be described, on the one hand, as parliamentarians from NPs seeing their own competences undercut by a strong EP or outright opposition by NPs' parliamentarians to an empowerment of the EP - or vice versa. However, it might also mean that parliamentary actors try to deal with an issue on their own parliamentary level due to competing visions of policy outcomes. Potential observable implications are parliamentary actors who insist on their exclusive competence in a policy, or parliamentary actors who gather legal expertise in order to substantiate their competence claims on a particular policy.

\section{Explaining multilevel party cooperation}

The subsequent question is: when we can expect the interaction between MPs and MEPs to move towards the cooperative end of the continuum? First, scholars assume a path-dependent increase in cooperation over time (Eppler and Maurer 2017: 243). Raunio (2000) has shown how transnational contact between parliamentarians grew in the 1990s, in parallel with the EP's empowerment. In trade politics, we may expect a 'pragmatic adaptation' (Rosén 2016) of parliamentarians to the new Lisbon Treaty provisions empowering the EP and NPs (Jančić 2017). Taking into account parliamentary rights at both the supranational and the national level, and that each actor could be a potential veto player in the negotiation of (mixed) trade agreements, we might expect a pragmatic adaptation to this new reality of enhanced rights on both levels, and hence increased levels of cooperation. Indeed, in trade negotiations, we observe a steady institutional rapprochement between the EP and NPs in forums like COSAC or the Conference of the Speakers of EU Parliaments (EUSC). Since NPs in EU member states, including their parties and parliamentarians, however, are equally affected by the changes introduced by the Lisbon Treaty, it does not lend itself well to explore variation of interaction among EU member states, especially at the level of political groups.

Second, scholarship suggests stronger interactions in cases of EU decisions that have major effects on member states, which encompass decisions falling within shared competences or binding international agreements (Bolleyer 2010: 418; Senninger and Bischof 2018; Strelkov 2015). In the case of trade policy, we are concerned with binding international agreements which include EU exclusive and/or shared competences. The legal ramifications of trade agreements differ depending on whether they include only EU-exclusive competences - where EP ratification suffices - or also shared competences, when ratification by NPs is required as 
well (Jančić 2017). Indeed, the CETA and TTIP were treated as mixed agreements, and thus ratification on the EU-Canada deal was required by both NPs and the EP.

One may argue that these mixed agreements, the CETA and TTIP, provide significant incentives for NPs' parliamentarians to engage in relations with the EP even if they were not politicized - compared to EU-only agreements such as the deals with Japan or Singapore. However, the 'mixity' of trade agreements is often a result of a political bargain between the Commission and the Council (Jančić 2017) and this was the case for the CETA when the Commission proposed on 5 July 2016 to classify the deal as a mixed agreement (Commission 2016). For the large part of our period of observation (2013-18), it was therefore not clear to parliamentarians whether these trade deals would be mixed or EU-only agreements. Keeping this in mind, the legal differences between the CETA and TTIP, on the one hand, and trade deals with other countries like Japan, on the other hand, are, in these concrete cases, not well equipped to explain variation of multilevel party relations. In addition, as we will show in the empirical section of this article, we explore variation of these relations across parties in Austria, Germany and Sweden which are affected to the same extent by the binding decisions through trade agreements.

Third, scholars observe variations in multilevel party relations across member states and their respective parliaments (Winzen et al. 2015). One important factor that accounts for such variation is institutional strength of parliaments (e.g. Auel et al. 2015). Yet, the NPs we selected for our study all display high levels of institutional and administrative capacity. According to the ranking by Katrin Auel et al. (2015), the German Bundestag, Swedish Riksdag and Austrian Nationalrat score highly, at levels above 0.7 for the former two and above 0.5 in the latter case (on a scale of 0 to 1). Even if the score of the Austrian Nationalrat is slightly lower than those of Germany and Sweden, scholarship considers the Nationalrat as strong as the German Bundestag (Pollak and Slominski 2003). We intentionally select institutionally strong NPs in order to hold their capacity in scrutinizing EU affairs constant. Still, we find variation in relations among the political groups across these NPs.

In brief, we know from existing research that NPs' engagement in EU affairs and consequently relations between MEPs and MPs are likely to be affected by the magnitude of EU-only or mixed-trade agreements and by parliaments' institutional strength. Yet, for the reasons outlined above, these agreement-specific and NP-related factors cannot explain the variation we observe across parties in the Austrian, German and Swedish parliaments. We turn to partisan-level factors in the next subsection in order to build theoretical expectations for how and why multilevel party relations across the EP and NPs vary in EU trade politics.

\section{Multilevel party politics}

In order to explore multilevel party relations, it is crucial to examine the political incentives of parliamentarians. An underlying assumption is that parliamentarians need to be responsive to citizens and tackle salient issues (Raunio 2011). Issues that are politicized among domestic constituencies are likely to receive more attention, leading to a higher investment of resources by parliamentarians compared to less 
politicized issues (Miklin 2014). Hence, it should be likely that we will observe dynamics of party interactions in these instances. However, we propose that partisan-level factors moderate such interactions. In other words, we expect partisan-level factors to condition the direction of competitive versus cooperative multilevel interactions. Below, we delineate a theoretically deduced pathway that we hold to be the most likely route to cooperation.

On a general level, we assume the direction of the dynamics depends on a convergence or divergence of actors' preferences. In cases where party groups across vertical levels have convergent preferences, we expect to observe cooperative relations. Whereas when party groups in the EP and NPs diverge regarding preferences over political issues, relations are likely to be rather competitive. On a more finegrained level, we contend that three conditions lead multilevel relations towards cooperation on politicized issues (Figure 1). More specifically, we expect a combination of these three conditions to account sufficiently for EP-NP cooperation on a partisan level. First, the literature indicates variations in cooperation between opposition parties and those in government (Herbel 2017; Miklin 2013; Mühlböck 2012). This is because national MPs can obtain information not only from the EU level but also direct and often more exhaustive information from their national government (Raunio 2009). Parties in government can be assumed to be in much closer contact with the executive from which they receive privileged information. Opposition parties, in contrast, are likely to have no privileged access to the national government, and the information that they receive might be biased in favour of the executive's position. Annika Herbel (2017), for example, shows that opposition parties try to reduce their information asymmetry through a close scrutiny of EU matters. Consequently, opposition parties have larger incentives to balance the information they receive from government with expertise and information from other actors - such as their EP group (Crum and Fossum 2013: 260ff.; Finke and Herbel 2015; Miklin 2013; Strelkov 2015).

Second, the findings by Thomas Winzen et al. (2015) suggest that multilevel relations vary according to NPs and their parliamentarians' attitude towards European integration and the EP's empowerment. The assumption is that those NPs that are friendly towards the EP perceive it as a potential ally with which they can strive for synergy effects in scrutinizing executive actors (Winzen et al. 2015). Therefore, it is reasonable to expect cooperation for EP-friendly MPs compared to those who are critical of the EP's empowerment in general. This reasoning is congruent to research on partisan variation of multilevel party relations, according to which culturally liberal groups are expected to engage much more in cooperation, while culturally conservative groups in NPs are more likely to perceive the EP as a competitor (Winzen et al. 2015).

A third factor mediating the direction of multilevel party relations is the cleavage between protectionism and free trade, which is specific to our case study. ${ }^{1}$ We contend that those party groups in favour of protectionism are more likely to invest in multilevel cooperation compared to parties supporting free trade. First, actors are likely to invest more political resources when they face situations where they expect to lose out on their demands (Meissner and McKenzie 2019). Second, in the negotiation of trade agreements actors in favour of protectionism are unlikely to share the executive's position in favour of free trade, be it the Commission, the Council or 


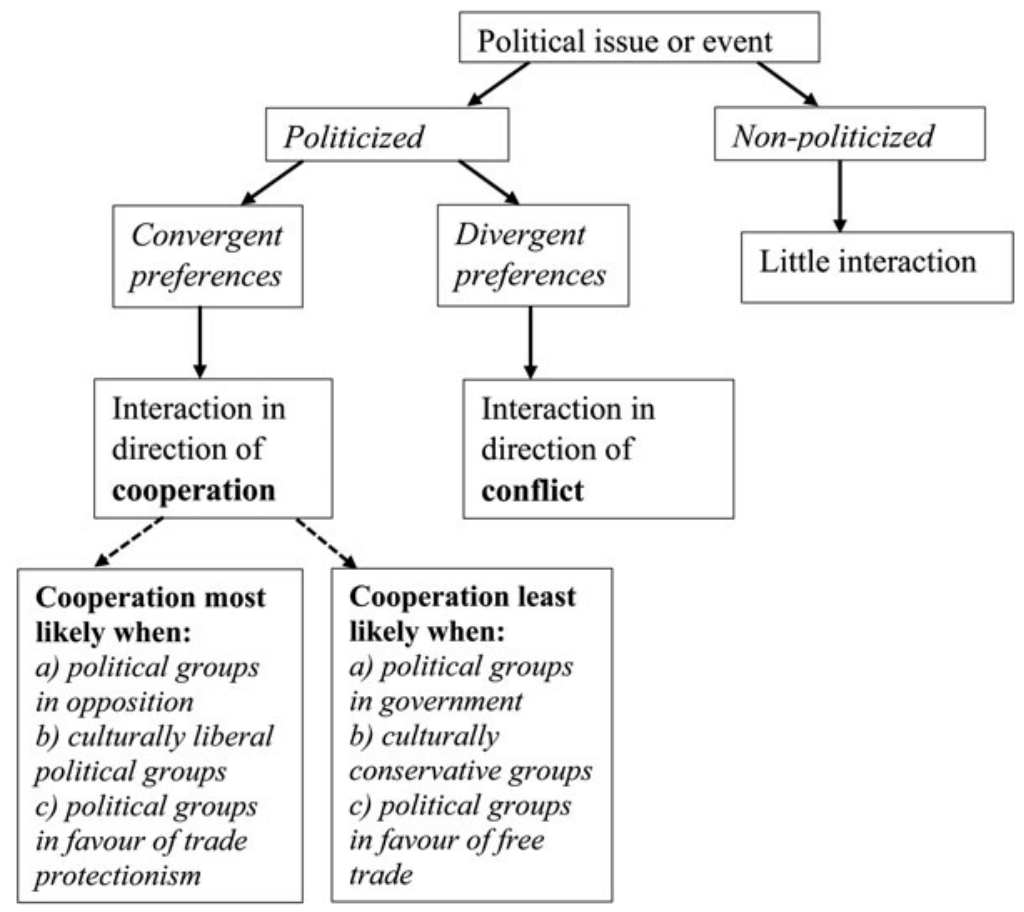

Figure 1. Path to Multilevel Party Cooperation Source: Authors' own creation.

national governments. Earlier studies find that disagreement with the executive's position is a crucial motive for parties to become active on EU matters (Finke and Herbel 2015). Hence, parties in favour of protectionism need to mobilize more political resources in order to promote their position compared to actors who share the dominant, executive position in favour of free trade.

Tying these arguments together (Figure 1), we assume that multilevel party interactions are likely on politicized issues compared to less salient political events. Yet, partisan-level factors moderate the direction of these relations: under the condition of convergent preferences, multilevel party interaction is most likely to tend towards the direction of cooperation for: (a) political groups in opposition; (b) culturally liberal parties; and (c) groups favouring trade protectionism. We expect that these three factors - when combined - are a sufficient trigger for multilevel party cooperation.

\section{Research design}

In assessing our expectations, we pursue a two-step research strategy. First, our article is based on a comparative design where we investigate multilevel party interactions in a set of similar NPs in Austria, Germany and Sweden (Gerring 2007: 132). Parliaments in these countries are all institutionally strong and equally affected by the changes of the Lisbon Treaty and by EU trade agreements. We intentionally 
selected institutionally strong NPs in order to hold their administrative capacity, as one potential factor for multilevel party cooperation, constant. The countries differ, however, regarding the level of politicization of the CETA and TTIP negotiations. Whereas both agreements were highly politicized in Austria and Germany, the negotiations were rather low-key in Sweden, the CETA more so than the TTIP (Rosén 2019). Thus, we have chosen two countries where trade has been highly contested - Austria and Germany - as well as a country were both contestation and engagement has been relatively low, namely Sweden. Through within-case comparison, we check for less politicized trade negotiations in Austria and Germany in our interview data in order to maximize confidence in our findings.

We combine our comparative research design with a minimalist type of explaining-outcome process-tracing (Beach and Pedersen 2019). A minimalist form of process-tracing is particularly appropriate when a researcher seeks to explore whether empirical evidence exists in favour of a particular pathway among a range of possible alternative ones (Beach and Pedersen 2019: 3). Compared to other types of process-tracing, a minimalist form does not unpack the concrete steps in a causal mechanism, but focuses on establishing a pathway, as in our case, between politicization and multilevel party cooperation (Beach and Pedersen 2019: 35). Furthermore, we understand our minimalist process-tracing as an explaining-outcome one which seeks to identify a minimally sufficient path to a particular outcome (Beach and Pedersen 2019: 12). It assumes that a combination of different conditions might be required to account sufficiently for an outcome - in our case multilevel party cooperation. In this article, the minimalist explaining-outcome process-tracing we pursue is deductive. Based on our theoretical expectation that there is not one single factor that is sufficient to explain multilevel party cooperation, and congruent with explaining-outcome process-tracing, we explore the constellation of three factors: government versus opposition parties; culturally liberal versus culturally conservative groups; and parties in favour of free trade versus parties in favour of protectionism. In the empirical section, we assess which constellation of these is able to trigger the outcome. Again there are some key differences between the three selected countries that allow us to explore the impact of the various conditions. Austria and Germany both had the same parties in government throughout the period. In Sweden there was a shift in 2014, where a coalition between the Social Democrats and the Greens took over office from a coalition of moderate parties. ${ }^{2}$ Furthermore, the three countries display variable patterns of cultural liberalism and trade protectionism.

Based on the 2019 Chapel Hill Expert Survey (CHES), we classified the parties on a culturally liberal to culturally conservative axis. The placement is based on the parties' views on social and cultural values (GAL-TAN) (Bakker et al. 2020). The scale runs from 0 (libertarian/postmaterialist), via 5 (centre), to 10 (traditional/ authoritarian). We categorized parties which score above 5 as traditionalist. To determine which political parties are more protectionist, we build on CHES and use the parties' position on trade liberalization/protectionism (Bakker et al. 2020). ${ }^{3}$ The scale runs from 0 (strongly favours trade liberalization) to 10 (strongly favours protection of domestic producers). We categorize parties who score above 5 as protectionist. The categorization of parties is shown in Table 2, which also includes information on which parties were in government during the period 
Table 2. Allocation of Conditions Regarding Party Groups in Austria, Germany and Sweden

\begin{tabular}{|c|c|c|c|}
\hline & Austria & Germany & Sweden \\
\hline Culturally liberal & $\begin{array}{l}\text { Grüne, Neos, } \\
\text { SPÖ }\end{array}$ & $\begin{array}{l}\text { Die Linke, Bündnis } \\
\text { 90/Die Grünen, FDP, SPD }\end{array}$ & $\begin{array}{l}\text { MP, V, SAP, FP/L } \\
\text { (from 2015), C }\end{array}$ \\
\hline Culturally conservative & FPÖ, ÖVP & $\mathrm{AfD}, \mathrm{CDU} / \mathrm{CSU}$ & $\mathrm{SD}, \mathrm{KD}, \mathrm{M}$ \\
\hline Government & ÖVP, SPÖ & CDU/CSU, SPD & $\begin{array}{l}\text { M, C, FP/L, KD (until } \\
\text { October 2014); SAP, MP }\end{array}$ \\
\hline Opposition & $\begin{array}{l}\text { FPÖ, Neos, } \\
\text { Grüne }\end{array}$ & $\begin{array}{l}\text { Bündnis 90/Die Grünen, Die } \\
\text { Linke, FDP, AfD }\end{array}$ & $\begin{array}{l}\text { SAP, MP (until October } \\
2014) ; \mathrm{M}, \mathrm{C}, \mathrm{KD}, \mathrm{FP} / \mathrm{L}, \mathrm{V} \text {, } \\
\text { SD }\end{array}$ \\
\hline Trade protectionism & $\begin{array}{l}\text { SPÖ, Grüne, } \\
\text { FPÖ }\end{array}$ & AfD, Die Linke, & $\mathrm{V}, \mathrm{SD}$ \\
\hline Free trade & Neos, ÖVP & $\begin{array}{l}\text { CDU/CSU, FDP, Bündnis } \\
\text { 90/Die Grünen, SPD }\end{array}$ & $C, M, F P / L, K D, M P, S A P$ \\
\hline
\end{tabular}

Source: Authors' own compilation based on data in Bakker et al. 2020.

Notes: Details on the scores of the different parties can be found in the Online Appendix. SPÖ = Sozialdemokratische Partei Österreichs, FPÖ = Freiheitlich Partei Österreichs, ÖVP = Österreichische Volkspartei, FDP = Freie Demokraten, SPD = Sozialdemokratische Partei Deutschlands, $A f D=$ Alternative für Deutschland, CDU = Christlich Demokratische Union Deutschlands, $\mathrm{CSU}=$ Christlich-Soziale Union, $\mathrm{SAP}=$ Socialdemokraterna, $\mathrm{KD}=$ Kristdemokraterna,

$\mathrm{M}=$ Moderaterna, $\mathrm{V}=$ Vänsterpartiet, $\mathrm{C}=$ Centerpartiet, $\mathrm{SD}=$ Sverigedemokraterna, $\mathrm{MP}=$ Miljöpartiet, $\mathrm{FP} / \mathrm{L}=$ Folkpartiet Liberalerna/Liberalerna.

under study. We triangulate and cross-check the categorization of these parties with data from our interviews (see below).

The data in this study are drawn from two main sources: first, we conducted 20 semi-structured interviews with parliamentarians and staff members both at the EU and national levels in all three countries. Second, we have collected a range of documentary data consisting of parliamentary reports, speeches and questions. In all three countries, we mapped the agendas of the relevant parliamentary committees between 2013 and 2018. Combining these sources provides us with a unique set of rich empirical materials (further information about the interviews and the parliamentary documents can be found in the Online Appendix).

\section{Multilevel party cooperation: the partisan dimension of EU trade negotiations}

Before we turn to an empirical investigation of multilevel party cooperation, we provide a brief backdrop of the state of play of EP-NP interaction on a parliamentary level in EU trade affairs. Looking into institutionalized interaction in COSAC, we observe a rapprochement between the EP and NPs over the years. Shortly after the Lisbon Treaty, the EP was reluctant to concede further rights to NPs in EU affairs (EP 2010-2011: 7). The case of trade reinforces this evaluation: initially, the EP focused on consolidating its new powers, wanting to keep NPs at arm's length; NPs, in turn, felt frustrated by the lack of information about EU trade negotiations (Interview 1). The EP's hesitation to acknowledge NPs as allies in EU trade politics changed substantially in 2014 when the EU was in the midst of negotiating the TTIP. During that time, the EP showed a renewed commitment to COSAC by having 
more delegates in the meetings (EP 2014-2015: 14). At the EUSC, all attendees highlighted the role of the EP and NPs in the negotiation of EU trade agreements (EP 2014-2015: 17-18). Furthermore, parliaments organized meetings and events on trade politics through COSAC and the EP's International Trade Committee, including a lunch debate on the CETA (EP 2014-2015). NPs clearly instigated this development (Roederer-Rynning and Kallestrup 2017). The EU-28 parliaments actively strove for access to documents, especially on the CETA and TTIP (Meissner and Rosén 2021). In 2014, for example, 21 chairs of NPs' relevant committees sent a letter to the Commission asking for the CETA and TTIP to be considered mixed agreements which would require national ratification. ${ }^{4}$ Even though NPs exerted pressure on the Commission to make the CETA and TTIP mixed agreements, allowing for national parliamentary ratification, this was not a contentious issue between the EP and NPs. ${ }^{5}$ Still, the Austrian Nationalrat and the German Bundestag in particular actively scrutinized the CETA and TTIP negotiations, as did the Swedish Riksdag, ${ }^{6}$ through access to documents (Interviews 2, 3, 4), meetings with executive actors (Interviews $5,6,7)$ as well as meetings including MEPs in national committees (background talk). Access to information on the CETA and TTIP improved substantially over time. This applies especially to the Austrian Nationalrat and German Bundestag, whose parliamentarians were eventually granted access to the negotiation documents in specific reading rooms (Meissner and Rosén 2021).

The subsequent question is whether there is also a similar turn towards more partisan cooperation across parliamentary levels. Below, we systematically identify the different forms of relations we observe in Austria, Germany and Sweden on the continuum developed in the theory section. Subsequently, we discuss our results and analyse them through our theoretical framework, based on which we expect multilevel party cooperation.

On a partisan level, our interview data point to a change over time in the benefit of interaction, echoing the observations from the parliamentary level described above. Interviewees widely acknowledged more multilevel party interactions in the highly politicized context of the CETA and TTIP negotiations compared to less salient agreements such as those with Japan or Singapore; this holds for all three assemblies. One Austrian interviewee, for example, made it clear that there was 'zero interest' in other negotiations such as the Japanese one (Interview 11, 12); another interviewee described the CETA and TTIP negotiations as completely different from other agreements (Interview 5). One Swedish interviewee described the considerable difference between the TTIP and the CETA in how MPs were involved. When the latter was to be ratified by the Council, it was treated as an A-point by the EAC, meaning that MPs could only respond in writing, without prior debate. Other EU trade agreements, which do not receive the same level of attention as the TTIP did, receive similar treatment (Interview 4). This confirms our expectation that the politicization of EU issues is a background condition for energetic multilevel party interactions. At the same time, as we show below, there are large variations between the patterns of cooperation and conflict across parties.

\section{Positive coordination}

When exploring partisan variation on our continuum of cooperation and competition, we are able to identify the Greens as a 'champion' of multilevel cooperation. 
Across the parties under investigation here, the Green parties stood out in coordinating their positions between the national and supranational levels, in organizing joint events and in launching press releases together (e.g. Interviews 9, 14, 15). According to an interviewee from Austria, out of all EU issues, the CETA and TTIP were the ones on which collaboration between Green MPs and MEPs had worked best to date (Interview 15). The level of cooperation in the case of the German Greens was equally high throughout the CETA and TTIP talks, parliamentarians and their staff members were in frequent contact via phone conversations, visits back and forth, and the German Bundestag's contact office in Brussels (Interview 14). ${ }^{7}$ The purpose of these contacts was to reap synergies in evaluating the negotiations (Interview 14) and to develop joint positions which could be represented by both MPs and MEPs (Interview 9). These efforts resulted in joint press releases (Interview 14), but also in joint activities such as an event on investment in trade agreements (Interview 9) or a joint anti-TTIP campaign (Interview 15). In the case of Sweden, too, Green parliamentarians were more likely to synchronize and coordinate their positions within the party. ${ }^{8}$ This included, for example, joint op-eds in national newspapers. ${ }^{9}$ Swedish interviewees describe coordination efforts concerning not only content, but also the political 'game' between governance levels. There are, for example, instances where parliamentarians at the two levels accommodate the strength of their message to ensure that a broad scope of policies is considered. While they know that a compromise has to be made, one level will express a more extreme viewpoint to increase the chances of including more perspectives into the decision-making process (Interview 13). According to the continuum, which we conceptualized in the theory section, we can classify these activities as examples of 'positive coordination' where actors coordinate their positions and develop joint positions.

\section{Negative coordination}

Compared to 'positive coordination', we find surprisingly little 'negative coordination' where parties divide labour or intentionally seek to avoid conflict. This is particularly surprising since NPs and their party groups were aware of the division of EU competences in trade politics, and this was indeed politically discussed. While the conservatives and social democrats in Germany, for instance, perceived the CETA and TTIP as an EU-only agreement (Interviews 8, 6), Austrian conservatives made it clear that both the EP and NPs needed to ratify those agreements (PK 830 2014). Hence, the division of competences was a contentious issue, but this did not result in much 'negative coordination' among the parties. Parliamentarians are nevertheless conscious of how tasks are divided across levels; this is a significant message from Swedish Social Democrats. While MEPs can scrutinize the Commission, through meetings and parliamentary questions, national MPs oversee and control the government. One of the interviewees also described how the knowledge and competence of MPs and MEPs complement each other, and how they stimulate a deliberate division of labour: MEPs know what is taking place at the EU level, but the MPs have a better overview of the party positions and know what policies have the best chances of being anchored both locally and nationally (Interview 7). In Austria, Social Democrats sought to avoid communicating 
incoherent political messages in public, taking into account both MEPs and MPs (Interview 16). Still, there are few concrete examples of negative coordination.

\section{Information exchange}

A general pattern in our empirical data is that MPs contact their European colleagues in order to access information that is hard to obtain in a national context. Again, the Green parties stood out in interacting through bilateral visits, informal requests for documents or an indirect exchange of documents via leaks to the public (Interviews 15, 10). All other parties, too, reported bilateral contacts (Interviews 8, $6,16,13$ ) or exchanges of information (Interviews 5, 2, 3, 16, 4, 13, 7) with three exceptions: the Austrian conservatives who according to an interviewee (11) did not interact across levels; and the German liberals who preferred not to interact with ALDE in order to not steer public attention (Interview 17). Interestingly, in the case of the Swedish Greens, the contact declined once the party entered into government (Interview 10). As we elaborate on below, this is a pattern we find in the case of several government parties - they receive information directly from their governments, which limits the need for contact with MEPs. Moreover, several interviewees underlined the importance of MEPs' knowledge about EU trade policy (Interviews 10, 4, 13). Exchange of information appears to take place rather informally, through direct contact between parliamentarians at both levels - albeit mainly at the request of MPs (Interview 7).

\section{Coexistence}

In addition to the forms of cooperation described above, the data on the CETA and TTIP contain some evidence in favour of coexistence. Parliaments engaged in efforts to gather expertise in order to be able to evaluate the negotiations themselves; these included: co-optation of and hearings with non-governmental organizations (Interview 15); hearings with experts, lawyers and Commission representatives like Trade Commissioner Cecilia Malmström (PK 937 2016; Riksdagen 2015b); and requests for access to negotiation documents directly addressed to the Commission (PK 144 2016). The president of the Austrian Nationalrat delegated to the parliament's administrative staff the task of gathering information from other EU-28 NPs about the degree of access to negotiation documents and the respective reading rooms (PK 34 2016), and agreed with Malmström directly that MPs would get a debriefing by the Commission after each bargaining round (PK 144 2016). Similarly, much of the activity of the Swedish Riksdagen was independent of Swedish MEPs. The open TTIP hearing in 2015 did not have any speakers from the EP, and trips to the USA to meet with members of Congress were a national undertaking. The TTIP was a topic of the EU committee on several occasions, and committee members held meetings with American officials, together with the Committee on Industry and Trade. The Riksdagen also held open hearings on the TTIP and received visits from Trade Commissioner Malmström, albeit not as often as the German and Austrian parliaments (Meissner and Rosén 2021). The Swedish government also informed the preparatory group of the Committee on EU Affairs, which is described as an informal forum for dialogue and knowledge 
transfer' about the TTIP negotiations (Riksdagen 2015a: 4). Based on our continuum, these measures qualify as coexistence in the form of a unilateral gathering of documents, expertise and information.

Notably, all of these activities resided with parliaments and their committees, however, rather than happening on a partisan level. In the German Bundestag, for example, hearings with experts and Commission representatives were organized on a committee level, similarly in Sweden. In Austria, the request for national ratification by a number of political groups was supported, at that time, by the government and did not provoke polarization within the parliament (PK 830 2014). Thus, this suggests that the quest for more legislative scrutiny rights in the CETA and TTIP resided with the committees of parliaments rather than with a specific party. This is an interesting finding as we know from research on the EP how the International Trade (INTA) committee can be a crucial driver of scrutiny in trade politics (Coremans and Meissner 2018). Our data indicate that similar dynamics occur in the committees of NPs, too.

\section{Conflict}

In our empirics, we did not find much multilevel conflict, and when we did, this took place at an institutional rather than a partisan level. When we found patterns of conflict in the form of a gathering of legal expertise, this was an endeavour by all parties, as was confirmed by interviewees (e.g. Interviews 3,15,18). In the Austrian Nationalrat, for example, MPs requested a review from the parliament's legal, legislative and scientific service regarding the division of competences in EU trade policy (PK 368 2016). Further reviews were collected from third parties (PK 720 2016). The parliament's constitutional committee, too, organized a hearing with experts on the legal aspects of the CETA, particularly the division of competences (PK 612 2017). As in the case for coexistence (see above), these reviews and hearings seem to have been organized, however, on a parliamentary or committee level rather than by a specific party. In the Swedish case, there are few examples of conflict, except in the case of the Greens, who in 2014 entered into government for the first time in history. This produced something of a schism in the relationship between the groups of the parliamentary assemblies, where the party at the national level would support the CETA and TTIP, while MEPs continued to speak out against the agreements (Interview 10).

\section{The pathway to multilevel party cooperation}

Above, we mapped interactions between parliamentarians across the EP and NPs in EU trade policy, and identified the levels of multilevel party cooperation in Austria, Germany and Sweden. In this section, we analyse the empirical patterns of multilevel party cooperation using the explanatory factors of our theoretical framework.

Our findings seem to confirm our expectation that party relations between the EP and NPs would be more active in the context of politicized trade agreements compared to less salient ones. Interviewees across parliaments and parties emphasized how their engagement and interaction with other legislative bodies was entirely different on the CETA and TTIP than in other trade negotiations. ${ }^{10}$ Agreements with lower levels of public attention such as the ones with Japan or 
Singapore received almost no consideration at the national parliamentary level. Even the Greens, which we were able to map as a champion of multilevel party cooperation, engaged significantly less across the supranational and national levels on such low-key EU trade agreements compared to the CETA and TTIP.

The direction of multilevel party activities was conditioned, however, by partisan differences. Our findings suggest that a pathway towards multilevel party cooperation rests on culturally liberal political groups which are in opposition and favour trade protectionism. As theoretically expected, and in line with previous research (Neunreither 2005), we find that the Greens - as a culturally liberal group in opposition and in favour of trade protectionism - stand out on the extreme of 'positive coordination' across all three countries. In fact, we do not find the same degree of cooperation for most other political groups, one exception being the Swedish Left Party, which we return to below.

First, the data suggest that the parties' position on free trade conditioned their interaction with the EP level. The Swedish Social Democrats, for example, did not coordinate extensively as they are firm pro-traders, which stands in contrast to what we find for the two most ardent protectionists in Sweden - the Left Party and the Greens. While, according to the CHES data (Bakker et al. 2020), the protectionism scores of both the Swedish Social Democratic and Green parties are average, our interview and document data show that the former was a strong promoter of both the TTIP and the CETA, while the latter expressed strong reservations, until they entered government. Another example stems from interviews with the Social Democrats in Austria, who reported activities in the form of negative coordination, but not positive coordination: finding ways to avoid communicating incoherent messages to the public (Interview 19, 16). Positive coordination was impaired by MPs and MEPs having conflicting sentiments towards the CETA - whether to support the agreement or not (e.g. PK 1091 2014). Among the German Social Democrats, too, positive coordination could not emerge partly due to the divergent preferences regarding free trade versus protectionism within the party, as an interviewee made clear (Interview 20). A similar observation is made in the case of the Swedish Greens after the party entered government in 2014. While MEPs continued their criticism of the TTIP and CETA, MPs followed the government line, which clearly favoured both agreements. According to interviewees, this change of direction from the national party coincided with a decrease in interaction between MPs and MEPs (Interview 10). The Greens in Austria and Germany, by contrast, had clearly converging preferences for trade protectionism throughout the CETA and TTIP negotiations, which was one condition enabling them to strive for positive coordination. Again, while the German Greens are categorized as pro-free trade according to the CHES data (Bakker et al. 2020), our interviewees reported a clear anti-TTIP and anti-CETA position.

Second, the ideological orientation of parties matters in that less culturally liberal parties seem to be less likely to engage in multilevel coordination. Again the Greens stand out as champions of positive coordination, and the Left Party in Sweden, too, engaged in coordinative practices - including, for example, joint op-eds in Swedish newspapers as described above. As both parties - the Greens and the Left Party in Sweden - are culturally liberal, this conforms to our theoretical expectation of when multilevel party cooperation will occur. We do not find the same degree of 
cooperation for other parties. While this might be unsurprising for parties in government (see below) or for parties with diverging preferences regarding free trade (see above), we would have expected to find positive coordination for parties like the Left Party in Germany, which has a record of being culturally liberal, in opposition, and with a clear preference for trade protectionism. Yet, this group focused primarily on information exchange and did not engage much in joint events (Interview 5). One reason for this might be that the German Left Party is not clearly as culturally liberal as it seems at first glance. Even though the German Left Party falls into the category of culturally liberal, the party's GAL-TAN score is, in fact, on the brink between libertarian and centre with a score of 4.9 (where 5 equals centre) according to the CHES survey (Bakker et al. 2020). The German Green Party, in comparison, has a clear libertarian/postmaterialist score of 2.1 (Bakker et al. 2020). This might go some way towards explaining the finding of negative multilevel party cooperation in the case of the German Left Party. Their main political arena is the national one.

Finally, there is a marked difference between opposition and government parties, yet it is in line with parties' position vis-à-vis the executive and their ideological orientation. Across all parliaments, there is little doubt that there was a felt difference between being inside and outside government offices - for example, in terms of how dependent opposition parties were on information from their respective MEPs. MPs from the government parties had access to several ministers as well as ministries and did not have much need for dialogue with MEPs (Interviews 7, 11, 19). Even though MPs from all three countries benefited from the CETA and TTIP reading rooms, this did not change their patterns of information exchange with MEPs. Rather, it appears that enhanced access to documents from the Commission made an exchange with MEPs even more pertinent in order to evaluate and select high-quality information from the overall flow of information (Interview 21; see also Coremans 2020). When the Swedish Green Party entered the coalition government with the Social Democrats in 2014, its MPs seem to have relied less on information from their European colleagues (Interview 10). While this indicates support for the government-opposition expectation, there was also a clear divergence between the two parliamentary levels from this point onwards, which accounts for a lack of cooperation, as described above. MPs from the Swedish Left Party in turn expressed their frustration at the lack of opportunity to voice their disagreement with the official Swedish position. In a meeting of the Committee on EU Affairs in Riksdagen, Jens Holm (Swedish Left Party) was told by Foreign Minister Wallström that his opposition to the deal could not be raised to the EU level because it was not to be part of the conclusions in the European Council. This clearly reflects the disadvantage of being in opposition:

We relate to the Swedish position, of which the TTIP is part. I really do not know what to do, because we relate to the Swedish position, where our dissenting view on the TTIP is firm. If the TTIP is not part of the Council conclusions, it really is strange for it to be part of 'our position'. (Jens Holm (Swedish Leftist party), Riksdagen, 2015c; author's translation)

At the same time, parties in opposition which favoured free trade were far less dissatisfied. The liberal groups in Austria and Germany, for example, reported that 
there was little need for multilevel party coordination (Interviews 2, 3) since they shared the executive's position in favour of the trade deals. In Sweden, too, parties which supported free trade agreements did not see access to information as a problem to the same extent as the parties that wanted stronger regulation of trade policy (Interview 7). Hence, there was more interaction at the cooperative end of the scale between rather protectionist parties. Again, the difference between the Swedish Greens inside and outside government provides a good illustration of this dynamic. Outside government they followed a pro-regulation line but changed strategy once in coalition with the free trade-friendly Social Democrats. These changed dynamics of being outside versus inside government and of being in favour of trade protectionism versus free trade were reflected in the levels of multilevel party relations from more to less cooperation.

Summing up, we observe that both politicization and convergent preferences are necessary for multilevel party cooperation to take place. Studying the differences between trade agreements across countries showed that cooperation took place in the cases of the CETA and TTIP but was negligible in the cases of Japan and Singapore. In Sweden, the TTIP was more politicized than the CETA and there was more cooperation on the TTIP than on the CETA. Furthermore, we saw that in the instances where the national party and the EP party group had diverging positions on the TTIP and/or CETA, cooperation deteriorated. This was the case for the Austrian and German Social Democrats and the Swedish Greens. At the same time, this alone is not sufficient to account for the variations in patterns of cooperation across parties. Analysing the impact of ideological orientation, position on trade policy and office-holding versus opposition parties, our findings confirm that culturally liberal opposition parties which contest trade liberalization are more cooperative. Again, however, neither of these conditions can account for multilevel party cooperation alone. Instead it is combining these factors that allows us to understand the dynamics of multilevel party cooperation. Culturally liberal parties in office can rely on information directly from the government. Culturally liberal parties in opposition which nevertheless support the government's position have less need to cooperate closely. However, if an issue is politicized and the policy position of MEPs and MPs converge, we can expect to see more cooperation when parties are culturally liberal and in opposition, and if their position is in conflict with that of the government. Hence, only a combination of opposition status, being culturally liberal and opposing the executive's position, is a sufficient trigger for multilevel party cooperation.

\section{Conclusion}

In this article, we aimed to explore multilevel party interactions across the EP and NPs and how these relations played out in EU trade policy. To this end, we first conceptualized a continuum ranging between cooperation, coexistence and competition to assess multilevel party relations. Second, we developed a theoretical framework to account for cooperative relations which we applied to the empirics of relations among party groups across the EP and NPs in EU trade policy, focusing on recent trade agreements.

The default of multilevel party relations seems to be an information exchange among MEPs and MPs, while we find remarkably little conflict or competition. 
We observe several instances of cooperation - positive or negative coordination and information exchange - where groups of the same party family, across the supranational and national levels, actively coordinate their preferences and launch joint strategies such as events or press releases. Going beyond the dichotomy of cooperation and conflict also allowed us to shed light on the spectrum of interaction that takes place between parliamentarians and that plays an important role in coordinating the activities between the EU level and the national level. More specifically, the Green party groups emerge as champions of cooperation which strove for synergies to mobilize against the CETA and TTIP negotiations. On an analytical level, the cooperation among the Greens from all three assemblies - the Austrian Nationalrat, German Bundestag and Swedish Riksdag - confirms our theoretical expectation: it was the culturally liberal groups in opposition and in favour of trade protectionism which engaged in multilevel cooperation on the highly politicized CETA and TTIP talks. The changing dynamic resulting from the Swedish Greens' entry into government supports this inference. Moreover, our empirical findings suggest that parliamentarians' convergent preferences on an EU issue and coherence within the same party family is an important background condition for multilevel cooperation to occur. Thus, the divergent and indecisive preferences of the German Social Democrats as well as the Swedish Greens were a hindrance to cooperation. This qualifies the impression of 'close ties' between parliamentarians at the national and EU levels (Senninger and Bischof 2018: 157). Overall, these findings also reinforce our assumption that multilevel cooperation on politicized EU issues is conditioned by factors rooted in a partisan dimension. Yet, only a combination of opposition status, being culturally liberal and opposing the executive's position, is a sufficient trigger for multilevel party cooperation.

While our study is restricted to multilevel party relations in EU trade politics, we believe that we open some fruitful avenues for further research. First, the continuum between cooperation, on the one hand, and competition, on the other hand, is a useful tool to investigate relations among parties and parliaments in the EU and multilevel governance systems more generally. Since the empirical findings in this article hint at parallel layers of varying relations on an institutional as compared to a partisan level, studies are needed on the mixed motives parliamentarians might face. How MEPs and MPs react in such situations of different goals remains an area for further research. Second, our findings suggest the partisan dimension is crucial for multilevel interaction in the EU. In addition to parties' opposition status, culturally liberal orientation and opposition to the executive's position, their internal coherence mattered for the interactions across the EU and national levels. Since coherence within the party family seems to be an important factor shaping multilevel interaction, future studies should shed more light on the internal dynamics within a party and their relevance for interparliamentary relations in the EU. Third, our investigations are restricted to EP and MEP relations with parliaments and parliamentarians in Austria, Germany and Sweden in the concrete negotiations of the CETA and TTIP. In order to explore the external validity of our theoretical framework and to establish an exhaustive mapping of more parliaments and their parliamentarians on the continuum, we see the need for further research. 
Supplementary material. The supplementary material for this article can be found at https://doi.org/10. 1017/gov.2021.52.

Acknowledgements. Earlier versions of this article were presented at workshops at the Institute for European Integration Research in Vienna (25-26 October 2018) and the University of Luxembourg (3-4 October 2019). We thank the participants and in particular Katrin Auel, Ben Crum and Henning Deters for helpful comments. Katharina Meissner is the recipient of an FWF project (M-2573). Guri Rosén has received funding from the Research Council of Norway (project number 303100). Open access funding provided by the University of Vienna.

\section{Notes}

1 While this particular cleavage is specific to our case study, we assume that the rationale behind it in mediating the direction of multilevel party relations, and as set out in this paragraph, can be at work in other instances of polarized issues too. A recent example of EU politics is the management of the refugee crisis which was politicized in public, and regarding which opposition parties in countries such as Austria contested the government's position. Here we would expect multilevel party cooperation for parties that are opposed to the executive's position rather than for those opposition parties which share the executive's position regarding the refugee crisis.

2 The Social Democratic Party and Green Party entered office in 2014. They replaced the Moderate Party, Centre Party, the Christian Democrats and the Liberals.

3 An alternative source could be the Comparative Manifesto Project. The problem is that not all parties have scores on relevant variables (support for free market economy versus protectionism, for example).

4 At this time, in 2014, it was legally and politically contested whether the CETA and TTIP were to be considered EU exclusive or mixed agreements.

5 In our semi-structured interviews, we inquired into multilevel party relations regarding the division of competences in the CETA and TTIP negotiations by asking two questions. First: NPs need to ratify CETA. What was/is the respective position of your party group? Second: How did/do you perceive the EP's position on the fact that NPs need to ratify the CETA?

6 Albeit more on the TTIP than on the CETA, as we describe below.

7 EU-28 parliaments have representatives based in Brussels. In the case of the German Bundestag, the contact office in Brussels hosts representatives from the parliament's staff next to representatives from each political group in the Bundestag.

8 Albeit more on TTIP than on CETA, which was not highly politicized in Sweden.

9 MEP Carl Schlyter (MP from 2014) and MP Ken Nordqvist, for example, had a series of op-eds discussing the TTIP in Svenska Dagbladet (a Swedish daily newspaper) in the autumn/winter of 2013.

10 In Sweden we also see a difference between the CETA and the TTIP - the former being less politicized than the latter.

\section{References}

Auel K, Rozenberg O and Tacea A (2015) To Scrutinise or Not to Scrutinise? Explaining Variation in EU-Related Activities in National Parliaments. West European Politics 38(2), 282-304. https://doi.org/ 10.1080/01402382.2014.990695.

Bakker R, Hooghe L, Jolly S, Marks G, Polk J, Rovny J, Steenbergen M and Vachudova MA (2020) 2019 Chapel Hill Expert Survey Version 2019.1. www.chesdata.eu. Chapel Hill: University of North Carolina.

Beach D and Pedersen RB (2019) Process-Tracing Methods: Foundations and Guidelines, 2nd edn. Ann Arbor: University of Michigan Press.

Bolleyer N (2010) Why Legislatures Organise: Inter-Parliamentary Activism in Federal Systems and Its Consequences. Journal of Legislative Studies 16(4), 411-437. https://doi.org/10.1080/13572334.2010. 519454 .

Carter E and Poguntke T (2010) How European Integration Changes National Parties: Evidence from a 15-Country Study. West European Politics 33(2), 297-324. https://doi.org/10.1080/01402380903538930.

Commission (2016) European Commission Proposes Signature and Conclusion of EU-Canada Trade Deal. 5 July. http://trade.ec.europa.eu/doclib/press/index.cfm?id=1524. 
Cooper I (2015) A Yellow Card for the Striker: National Parliaments and the Defeat of EU Legislation on the Right to Strike. Journal of European Public Policy 22(10), 1406-1425. https://doi.org/10.1080/ 13501763.2015.1022569.

Coremans E (2020) Opening Up by Closing Off: How Increased Transparency Triggers Informationalisation in EU Decision-Making. Journal of European Public Policy 27(4), 590-611. https://oi.org/10.1080/13501763. 2019.1599043.

Coremans E and Meissner KL (2018) Putting Power into Practice: Administrative and Political Capacity Building in the European Parliament's Committee for International Trade. Public Administration 96(3), 561-577. https://doi.org/10.1111/padm.12400.

Crum B and Fossum JE (2009) The Multilevel Parliamentary Field: A Framework for Theorizing Representative Democracy in the EU. European Political Science Review 1(2), 249-71. https://doi.org/ $10.1017 /$ S1755773909000186.

Crum B and Fossum JE (eds) (2013) Practices of Interparliamentary Coordination in International Politics: The European Union and Beyond. Colchester: ECPR Press.

Eisele O (2017) Complementing, Competing, or Co-Operating? Exploring Newspapers' Portrayals of the European Parliament and National Parliaments in EU Affairs. Journal of European Integration 39(4), 435-451. https://doi.org/10.1080/07036337.2017.1281262.

EP (2010-2011) Report on 'Interparliamentary Relations between the European Parliament and National Parliaments under the Treaty of Lisbon' 2009-2014. www.europarl.europa.eu/cmsdata/226289/Annual\% 20Report\%202010-11.pdf.

EP (2014-2015) Relations between the European Parliament and National Parliaments under the Treaty of Lisbon. www.europarl.europa.eu/cmsdata/226249/Annual_report_relations_with_national_Parliaments_ 2014-15_web.pdf.

Eppler A and Maurer A (2017) Parliamentary Scrutiny as a Function of Interparliamentary Cooperation Among Subnational Parliaments. Journal of Legislative Studies 23(2), 238-259. https://doi.org/10.1080/ 13572334.2017.1329989.

Finke D and Herbel A (2015) Beyond Rules and Resources: Parliamentary Scrutiny of EU Policy Proposals. European Union Politics 16(4), 490-513. https://doi.org/10.1177\%2F1465116515584202.

Gerring J (2007) Case Study Research: Principles and Practices. Cambridge: Cambridge University Press.

Haroche P (2018) The Inter-Parliamentary Alliance: How National Parliaments Empowered the European Parliament. Journal of European Public Policy 25(7), 1010-1028. https://doi.org/10.1080/13501763.2017. 1423508.

Herbel A (2017) Parliamentary Scrutiny of the EU's Common Foreign and Security Policy. West European Politics 40(1), 161-182. https://doi.org/10.1080/01402382.2016.1240405.

Herranz-Surrallés A (2014) The EU's Multilevel Parliamentary (Battle)Field: Inter-Parliamentary Cooperation and Conflict in Foreign and Security Policy. West European Politics 37(5), 957-975. https://doi.org/10.1080/01402382.2014.884755.

Hix S (2002) Parliamentary Behavior with Two Principals: Preferences, Parties, and Voting in the European Parliament. American Journal of Political Science 46(3), 688-698. https://doi.org/10.2307/3088408.

Jančić D (2017) TTIP and Legislative-Executive Relations in EU Trade Policy. West European Politics 40 (1), 202-221. https://doi.org/10.1080/01402382.2016.1240407.

Lyder-Hermansen S (2018) (Self-)Selection and Expertise among Decision-Makers in the European Parliament. Journal of Legislative Studies 24(1), 148-172. https://doi.org/10.1080/13572334.2018. 1444631.

Meissner KL and McKenzie L (2019) The Paradox of Human Rights Conditionality in EU Trade Policy: When Strategic Interests Drive Policy Outcomes. Journal of European Public Policy 26(9), 1273-1291. https://doi.org/10.1080/13501763.2018.1526203.

Meissner KL and Rosén G (2021) Exploring Interaction between National Parliaments and the European Parliament in EU Trade Policy. In Fromage D and Herranz-Surrallés A (eds), Executive-Legislative (Im) Balance in the European Union. Oxford: Hart Publishing, pp. 195-208.

Metcalfe L (1994) International Policy Co-ordination and Public Management Reform. International Review of Administrative Sciences 60(2), 271-290. https://doi.org/10.1177\%2F002085239406000208.

Miklin E (2013) Inter-Parliamentary Cooperation in EU Affairs and the Austrian Parliament: Empowering the Opposition? Journal of Legislative Studies 19(1), 22-41. https://doi.org/10.1080/13572334.2013. 736785 . 
Miklin E (2014) EU Politicisation and National Parliaments: Visibility of Choices and Better Aligned Ministers? Journal of Legislative Studies 20(1), 78-92. https://doi.org/10.1080/13572334.2013.871486.

Miklin E and Crum B (2011) Inter-Parliamentary Contacts of Members of the European Parliament: Report of a Survey. RECON Online Working Paper 2011/08. Oslo. https://research.vu.nl/ws/portalfiles/ portal/2892125/RECON+wp+1108.pdf.

Mühlböck M (2012) National versus European: Party Control over Members of the European Parliament. West European Politics 35(3), 607-631. https://doi.org/10.1080/01402382.2012.665743.

Neunreither K (2005) The European Parliament and National Parliaments: Conflict or Cooperation? Journal of Legislative Studies 11(3-4), 466-489. https://doi.org/10.1080/13572330500273802.

Peters G (1998) The Challenge of Policy Coordination. Policy Design and Practice 1(1), 1-11. https://doi. org/10.1080/25741292.2018.1437946.

Pollak J and Slominski P (2003) Influencing EU Politics? The Case of the Austrian Parliament. Journal of Common Market Studies 41(4), 707-729. https://doi.org/10.1111/1468-5965.00442.

Raunio T (2000) Losing Independence or Finally Gaining Recognition? Contacts between MEPs and National Parties. Party Politics 6(2), 211-23. https://doi.org/10.1177\%2F1354068800006002006.

Raunio T (2009) National Parliaments and European Integration: What We Know and Agenda for Future Research. Journal of Legislative Studies 15(4), 317-334. https://doi.org/10.1080/13572330903302430.

Raunio T (2011) The Gatekeepers of European Integration? The Functions of National Parliaments in the EU Political System. Journal of European Integration 33(3), 303-21. https://doi.org/10.1080/07036337. 2010.546848.

Riksdagen (2015a) Activity in the European Union during 2014 (skr. 2014/15:65). Opinion of the EU Committee to the Committee on Foreign Affairs (2014/15: EUN1y) (Verksamheten i Europeiske unionen under 2014 - EU-nämndens yttrande), Stockholm, 17 April.

Riksdagen (2015b) Public Hearing about a Trade Agreement between the EU and the USA (TTIP) (Offentlige utfrågning om ett handelsavtal mellan EU och USA (TTIP). Stockholm, 23 April.

Riksdagen (2015c) Record of EU Committee Meeting (2014/15:39) (Uppteckningar ved EU-nämndens sammanträden). Stockholm, 18 June.

Roederer-Rynning C and Kallestrup M (2017) National Parliaments and the New Contentiousness of Trade. Journal of European Integration 39(7), 811-825. https://doi.org/10.1080/07036337.2017.1371710.

Rosén G (2016) A Match Made in Heaven? Explaining Patterns of Cooperation between the Commission and the European Parliament. Journal of European Integration 38(4), 409-424. https://doi.org/10.1080/ 07036337.2016.1141903.

Rosén G (2019) Proving Their Worth? The Transatlantic Trade and Investment Partnership and the Members of the European Parliament. Politics and Governance 7(3), 266-278. https://doi.org/10. 17645/pag.v7i3.2225.

Scharpf FW (1994) Games Real Actors Could Play: Positive and Negative Coordination in Embedded Negotiations. Journal of Theoretical Politics 6(1), 27-53. https://doi.org/10.1177\%2F0951692894006001002.

Scharpf FW (1997) Games Real Actors Play: Actor-Centred Institutionalism in Policy Research. Boulder, CO: Westview Press.

Senninger R and Bischof D (2018) Working in Unison: Political Parties and Policy Issue Transfer in the Multilevel Space. European Union Politics 19(1), 140-162. https://doi.org/10.1177\%2F1465116517733819.

Strelkov A (2015) Who Controls National EU Scrutiny? Parliamentary Party Groups, Committees and Administrations. West European Politics 38(2), 355-374. https:/doi.org/10.1080/01402382.2014.990699.

Winzen T, Roederer-Rynning C and Schimmelfennig F (2015) Parliamentary Co-Evolution: National Parliamentary Reactions to the Empowerment of the European Parliament. Journal of European Public Policy 22(1), 75-93. https://doi.org/10.1080/13501763.2014.881415.

\section{Interviews}

Interview 1 (2011), EP staff. 30 May 2011.

Interview 2 (2018), Staff of political group, Austrian Nationalrat. 15 June 2018.

Interview 3 (2018), Staff of political group, Austrian Nationalrat. 15 June 2018.

Interview 4 (2018), Member of Parliament, Swedish Riksdagen. 3 October 2018.

Interview 5 (2018), Staff of political group, German Bundestag. 3 May 2018. 
Interview 6 (2018), Staff of political group, German Bundestag. 4 May 2018.

Interview 7 (2018), Member of Parliament, Swedish Riksdagen. 11 October 2018.

Interview 8 (2018), Staff of Member of Parliament, German Bundestag. 3 May 2018.

Interview 9 (2018), Staff of political group, German Bundestag. 3 May 2018.

Interview 10 (2017), EP staff, Sweden. 19 April 2017 and 9 January 2020.

Interview 11 (2018), Member of Parliament, Austrian Nationalrat. 14 June 2018.

Interview 12 (2016), Swedish MEP. 1 November 2016.

Interview 13 (2018), Member of Parliament, Swedish Riksdagen. 3 October 2018.

Interview 14 (2018), Staff of Member of Parliament, German Bundestag. 3 May 2018.

Interview 15 (2018), Member of party, Die Grünen. 24 July 2018.

Interview 16 (2018), Member of Parliament, Austrian Nationalrat. 12 July 2018.

Interview 17 (2018), Staff of Member of Parliament, German Bundestag. 7 May 2018.

Interview 18 (2018), Staff of administration, German Bundestag. 29 May 2018.

Interview 19 (2018), Staff of political group, Austrian Nationalrat. 2 July 2018.

Interview 20 (2018), Staff of political group, EP. 9 October 2018.

Interview 21 (2018), Staff of political group, German Bundestag. 7 May 2018.

\section{Parliamentary documents}

PK 830 (2014) TTIP und CETA - Schlagabtausch über Vorgehensweise. www.parlament.gv.at/PAKT/PR/ JAHR_2014/PK0830/index.shtml.

PK 937 (2016) Enquete zu CETA und TTIP: Unterschiedliche Expertenmeinungen zur Freihandelspolitik. www.parlament.gv.at/PAKT/PR/JAHR_2016/PK0937/index.shtml.

PK 144 (2016) TTIP: Bures adressiert an EU-Handelskommissarin Malmström Forderung nach Leseraum im Parlament. www.parlament.gv.at/PAKT/PR/JAHR_2016/PK0144/index.shtml.

PK 34 (2016) TTIP: Bures erfreut über Leseraum für ParlamentarierInnen. https://www.parlament.gv.at/ PAKT/PR/JAHR_2016/PK0034/index.shtml.

PK 1091 (2014) Vorlagen: Petitionen. www.parlament.gv.at/PAKT/PR/JAHR_2014/PK1091/index.shtml.

PK 368 (2016) EU-Unterausschuss vertagt Diskussion zu CETA. www.parlament.gv.at/PAKT/PR/ JAHR_2016/PK0368/index.shtml.

PK 720 (2016) CETA: EU-Unterausschuss pocht auf Genehmigungsrecht des Parlaments. www.parlament. gv.at/PAKT/PR/JAHR_2016/PK0720/index.shtml.

PK 612 (2017) CETA: Verfassungsausschuss prüft rechtliche Grundlagen des Abkommens. www.parlament.gv.at/PAKT/PR/JAHR_2017/PK0612/index.shtml.

Cite this article: Meissner KL, Rosén G (2021). Who Teams Up with the European Parliament? Examining Multilevel Party Cooperation in the European Union. Government and Opposition: An International Journal of Comparative Politics 1-22. https://doi.org/10.1017/gov.2021.52 